\title{
Situasi Pembiayaan Kesehatan Untuk Manajemen Penyakit Tidak Menular Di Pelayanan Primer Berbagai Negara Selama Pandemi Covid-19
}

\section{Health Financing Situation of Non-Communicable Disease Management in Primary Care among Countries during the COVID-19 Pandemic}

\author{
Lukman Handoyo $^{1}$, Agus Setiawan ${ }^{2}$, Poppy Fitriyani ${ }^{3}$ \\ ${ }^{1}$ Program Studi Magister Ilmu Keperawatan, Peminatan Keperawatan Komunitas, \\ Fakultas Ilmu Keperawatan, Universitas Indonesia \\ ${ }^{2,3}$ Departemen Keperawatan Komunitas, Fakultas Ilmu Keperawatan, \\ Universitas Indonesia \\ E-mail Korespondensi: a-setiawan@ui.ac.id \\ Gedung Pendidikan dan Laboratorium FIK UI Jl. Prof. Dr. Bahder Djohan, \\ Kampus UI Depok Jawa Barat 16424 - Indonesia
}

\begin{abstract}
ABSTRAK
Di era pandemi COVID-19, klien dengan Penyakit Tidak Menular (PTM) di tatanan komunitas memiliki kendala dalam mengelola penyakitnya yang membutuhkan tenaga kesehatan. Kendala tersebut dapat dikarenakan pelayanan primer membatasi pelayanan kesehatan dasar seperti untuk kontrol dan pelaksanaan program pencegahan keparahan penyakit. Guna memberikan perawatan yang optimal, beberapa pelayanan primer di berbagai negara membuat inovasi, yakni memberikan pelayanan manajemen PTM secara virtual. Tetapi, hal tersebut ternyata memiliki hambatan, terutama berkaitan dengan alokasi pembiayaan kesehatan dan klaim pelayanan. Potret negara lain yang lebih maju atau kurang lebih sama dengan Indonesia perlu dipelajari sebagai dasar pengetahuan manajemen pelayanan primer, sebab di Indonesia studi tentang gambaran pembiayaan di pelayanan primer selama pandemi COVID-19 masih minim. Tujuan dari studi ini adalah untuk menyajikan gambaran dasar tentang situasi pembiayaan kesehatan untuk manajemen PTM di pelayanan primer berbagai negara selama pandemi COVID-19. Studi ini merupakan studi literatur yang menggunakan tiga database akademik sebagai media pencarian artikel ilmiah, yaitu PubMed, Scopus, dan Google Scholar. Hasil penelusuran ditemukan 7 artikel sesuai dengan kriteria inklusi dan teridentifikasi dari empat negara, yaitu Amerika Serikat, Australia, Pakistan, dan Prancis. Terdapat empat isu tema yang muncul, yaitu: (1) Keterbatasan Anggaran di Pelayanan Primer; (2) Klaim Pelayanan Konsultasi Digital; (3) Hak Klaim Asuransi Kesehatan Klien yang Tidak Terpenuhi; dan (4) Kebijakan Baru Pembiayaan Kesehatan. Secara umum, pembiayaan pelayanan primer diduga kuat masih tertinggal dibanding pelayanan sekunder. Perlu ditekankan, PTM berkontribusi tinggi pada morbiditas dan mortalitas masyarakat. Tetapi, itu mampu dicegah ketika pembiayaan di pelayanan primer untuk pelaksanaan program promotif dan preventif cukup adekuat.
\end{abstract}

Kata Kunci : COVID-19, Pelayanan Primer, Pembiayaan Kesehatan, PTM

\section{ABSTRACT}

In the era of the COVID-19 pandemic, clients with Non-Communicable Diseases (NCD) in community settings have problems managing diseases that require health workers. These problems can be caused by primary care limiting basic health services such as control and prevention programs for disease severity. In order to continue to provide optimal care, several primary care in various countries have made innovations, namely 
providing virtual NCD management services. However, this has disruptions, especially regarding the allocation of health financing. The purpose of this study was to present a basic description of the situation that occurs regarding health financing for NCD management in primary care in various countries during the COVID-19 pandemic. This study was a literature study that uses three academic databases for searching scientific articles, namely PubMed, Scopus, and Google Scholar. The search results found 7 articles that match the inclusion criteria of four countries: the United States, Australia, Pakistan, and France. Health financing for NCD management in primary care in various countries has different situations. There were four theme issues that arise: (1) Limited Budget in Primary Care; (2) Claims for Digital Consulting Services; (3) Unfulfilled Client Health Insurance Claim Rights; and (4) New Health Financing Policy. It can be concluded that, in terms of financing, primary care is still lagging behind secondary care. It needs to be emphasized, NCD greatly contributes to the incidence of community morbidity and mortality. However, all of these can be prevented when funding for primary care of promotive and preventive programs is sufficient.

Keywords: COVID-19, Health Financing, NCD, Primary Care

\section{PENDAHULUAN}

Di era pandemi Coronavirus Disease 2019 (COVID-19) seperti saat ini, beragam masalah pada berbagai tingkatan pelayanan kesehatan tidak dapat dihindarkan. Salah satunya adalah problematika tentang pembiayaan kesehatan di pelayanan primer (Cutler, 2020). Pembiayaan kesehatan merupakan aspek penting yang sangat mendukung jalannya roda pelayanan kesehatan untuk masyarakat. Secara umum, pembiayaan kesehatan dapat ditanggung oleh pemerintah, asuransi agensi swasta, atau biaya mandiri (Blumel et al., 2020; Nurmansyah \& Kilic, 2017). Meskipun terdapat beberapa skema pembiayaan kesehatan, tetapi tidak dapat dipungkiri bahwa skema utama yang menanggung beban kesehatan banyak masyarakat adalah pembiayaan dan asuransi dari pemerintah (Erlangga et al., 2019). Hal tersebut dapat dibuktikan dengan hasil survei yang menunjukkan, di Amerika Serikat lebih dari 55\% penduduknya sudah teregistrasi dalam skema asuransi kesehatan pemerintah (Collins et al., 2020). Bahkan di Australia, sekitar 87\% penduduknya memiliki asuransi kesehatan yang juga dijamin oleh pemerintah (Jolly, 2018).

Pelaksanaan pembiayaan kesehatan bersumber dari pemerintah sejatinya dapat dilakukan di fasilitas pelayanan primer, sekunder, maupun tersier. Namun, pembiayaan kesehatan di pelayanan primer sering mengalami problematika yang seolah tidak kunjung terselesaikan dibandingkan di tingkat rumah sakit. Sebab, alokasi dan klaim pembiayaan kesehatan di pelayanan primer tidak hanya bertujuan untuk mendanai kegiatan kuratif, tetapi justru menitikberatkan pada kegiatan promotif dan preventif (Mahendradhata et al., 2017). Contoh problematika yang terjadi adalah pelayanan primer di Amerika Serikat 
yang ternyata sekitar 90\% dari biaya tahunan perawatan kesehatan hanya dihabiskan untuk tatalaksana penyakit kronis dari pada untuk kegiatan promotif (Amadeo, 2021). Di tambah lagi, studi yang dilakukan oleh Unger \& Paepe (2019) mengungkapkan, di Amerika Serikat masyarakat kelas ekonomi menengah justru sering meminta pemerintah untuk mengurangi pembiayaan kesehatan karena mereka tidak merasakan dampak yang signifikan dari pengeluaran tersebut. Artinya, pembiayaan kesehatan yang ada di Amerika Serikat, sebanyak apa pun ternyata juga dirasa belum cukup untuk mencapai Universal Health Coverage (UHC), di mana masyarakat seharusnya mudah menjangkau semua bentuk pelayanan kesehatan dari mulai promotif, preventif, kuratif, hingga rehabilitatif (Wiseman et al., 2018).

Di tengah krisis kesehatan akibat dampak pandemi COVID-19, pergeseran prioritas pembiayaan kesehatan di pelayanan primer dapat berpotensi terjadi karena pemberian pelayanan kesehatan lebih berfokus pada manajemen kasus COVID-19, sehingga ada beberapa isu kesehatan yang sementara waktu tidak terlalu diprioritaskan, termasuk penyakit tidak menular (PTM). Hal tersebut dikarenakan World Health Organization (WHO) sudah memberikan ultimatum pada berbagai negara yang terdampak pandemi COVID-19 untuk menata dan mengalokasikan ulang pemrioritasan pembelanjaan guna kepentingan kesehatan (Barroy et al., 2020). Perlu dipertegas, bahwa pelayanan kesehatan lain seperti manajemen PTM bukan berarti tidak ada. Namun, jika membahas tentang setting di pelayanan primer, maka kegiatan semacam Pos Binaan Terpadu (Posbindu) serta edukasi dan kegiatan aktivitas fisik bersama yang mengundang massa jelas sangat dikurangi. Bahkan ada pelayanan primer yang memutuskan untuk meniadakan public program (status postponed) (Rhatomy \& Prasetyo, 2020). Penjelasan ini dapat diperkuat oleh hasil survei WHO yang menunjukkan lebih dari 50\% negaranegara di dunia menunda program skrining PTM di masyarakat serta lebih dari 53\% negara mengakui adanya hambatan dalam manajemen hipertensi, diabetes, dan penyakit kardiovaskuler selama pandemi COVID-19 (WHO, 2020). Artinya, pembiayaan untuk manajemen PTM tersebut turut berpotensi dikurangi dan mungkin saja dialihkan pada kegiatan lain yang lebih diprioritaskan (manajemen kasus COVID-19). Di sisi lain, PTM yang dapat direpresentasikan oleh penyakit stroke ternyata masih menjadi pembunuh nomor satu di dunia (GBD 2019 Diseases and Injuries Collaborators, 2020). Ditambah lagi dengan tidak terkontrolnya PTM seperti hipertensi, riwayat penyakit jantung, dan diabetes melitus, maka risiko tertular COVID-19 juga akan semakin meningkat (Chang et 
Lukman Handoyo, Agus Setiawan, Poppy Fitriyani : Situasi Pembiayaan Kesehatan Untuk Manajemen ....

al., 2021). Hal itu menunjukkan, pengelolaan PTM terutama aspek promotif dan preventif tetap menjadi hal yang sangat vital meski di era pandemi COVID-19.

Sebetulnya, demi tetap mengontrol masyarakat dengan PTM agar hidup sehat, terdapat beberapa pelayanan primer yang mengonversi dari pelayanan langsung manajemen PTM kepada program berbasis telehealth atau virtual care (Bielska et al., 2020; Gummidi et al., 2020). Namun, kegiatan tersebut ternyata masih memiliki kendala dan tantangan pula. Tidak semua klien dengan PTM siap dengan pengetahuan penggunaan teknologi serta ketersediaan gawai dan jaringan yang memadai (Annaswamy et al., 2020; Triana et al., 2020). Selain itu, kegiatan yang dikonversi secara virtual ternyata masih dihadapkan pada berbagai isu pembiayaan yang belum sepenuhnya jelas. Tujuan dari studi literatur ini adalah untuk memberikan gambaran dasar tentang situasi yang terjadi terkait dengan pembiayaan kesehatan untuk manajemen PTM di pelayanan primer berbagai negara selama pandemi COVID-19. Dengan mengetahui permasalahan pembiayaan yang terjadi pada pelayanan primer masing-masing negara tersebut, diharapkan studi literatur ini dapat menjadi referensi dalam memandang bagaimana idealnya pembiayaan kesehatan pada pelayanan primer di Indonesia untuk manajemen PTM selama era pandemi COVID-19.

\section{METODE}

Studi ini merupakan studi literatur yang menggunakan pendekatan tinjauan tradisional (traditional review). Literatur yang digunakan merupakan artikel ilmiah internasional yang didapatkan dari tiga database akademik, yaitu PubMed, Scopus, dan Google Scholar. Kata kunci yang digunakan dan saling dipadupadankan untuk mendapatkan artikel-artikel tersebut adalah: Health Insurance OR Health Economics OR Universal Health Coverage OR Health Budgeting OR Health Financing AND Primary Care OR Primary Health Care OR Community Nursing AND Non-communicable Disease AND COVID-19 AND Telehealth OR Digital Health. Penulis tidak melakukan penilaian kualitas artikel, dikarenakan metode yang digunakan dalam studi ini hanya bersifat tinjauan tradisional. Analisis terhadap artikel dilakukan secara tematik dengan mengidentifikasi keunikan, perbedaan, atau persamaan dari pembahasan masing-masing artikel. Secara umum, kriteria yang peneliti tetapkan untuk menetapkan artikel yang dipilih adalah: (1) artikel membahas tentang bagaimana konsep pembiayaan kesehatan dari pelayanan primer suatu negara spesifik untuk melakukan manajemen PTM selama pandemi COVID-19; (2) artikel menjelaskan inovasi yang dilakukan untuk 
mengupayakan pelayanan manajemen PTM di era COVID-19; dan (3) artikel ditulis dalam bahasa Inggris. Negara yang dipilih tidak ditentukan di awal, sebab ini adalah isu baru dan ketika memasukkan kata kunci di database akademik, peneliti tidak dapat memprediksikan negara mana saja yang sudah memiliki artikel ilmiah yang membahas tentang topik pembiayaan kesehatan. Selama memenuhi kriteria, maka akan diambil untuk ditelaah.

\section{HASIL}

Hasil penelusuran artikel dari online database ditemukan 7 (tujuh) artikel yang memenuhi kriteria peneliti untuk ditelaah. Berikut tabel hasil ekstraksi dari artikel yang dipilih:

Tabel 1. Hasil Ekstraksi Artikel

\begin{tabular}{|c|c|c|c|c|c|}
\hline No & $\begin{array}{c}\text { Author dan } \\
\text { Tahun } \\
\text { Publikasi } \\
\end{array}$ & $\begin{array}{c}\text { Nama Jurnal dan } \\
\text { Sumber Database } \\
\text { Akademik } \\
\end{array}$ & $\begin{array}{c}\text { Negara } \\
\text { yang } \\
\text { Dibahas }\end{array}$ & $\begin{array}{c}\text { Data Inti yang } \\
\text { Relevan }\end{array}$ & $\begin{array}{c}\text { Analisis } \\
\text { Tema }\end{array}$ \\
\hline 1 & $\begin{array}{l}\text { Domingues \& } \\
\text { Willis (2020) }\end{array}$ & $\begin{array}{l}\text { Journal of Primary Care } \\
\text { \& Community Health } \\
\text { Scopus }\end{array}$ & $\begin{array}{l}\text { Amerika } \\
\text { Serikat }\end{array}$ & 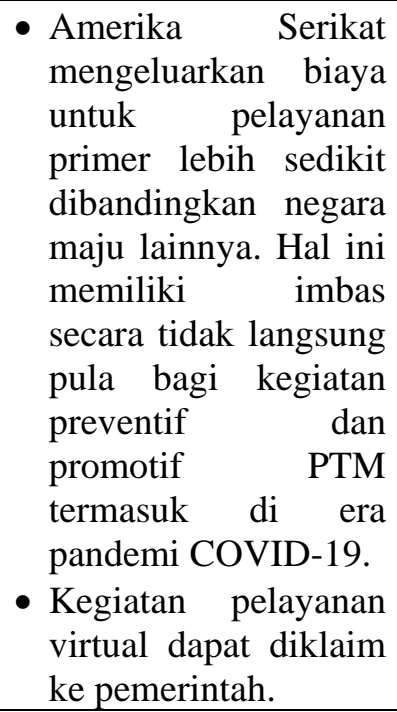 & $\begin{array}{l}\text { Keterbatasan } \\
\text { Anggaran di } \\
\text { Pelayanan } \\
\text { Primer } \\
\\
\text { Klaim } \\
\text { Pelayanan } \\
\text { Konsultasi } \\
\text { Digital } \\
\end{array}$ \\
\hline 2 & $\begin{array}{l}\text { Hartmann- } \\
\text { Boyce et al. } \\
(2020)\end{array}$ & $\begin{array}{l}\text { Diabetes Care } \\
\text { Scopus }\end{array}$ & $\begin{array}{l}\text { Amerika } \\
\text { Serikat }\end{array}$ & $\begin{array}{lr}\text { Banyak care provider } \\
\text { mengalihkan pelayanan } \\
\text { manajemen } & \text { diabetes } \\
\text { melitus pada } & \text { kegiatan } \\
\text { virtual care. } & \text { Namun, } \\
\text { tidak semua } & \text { hak } \\
\text { kesehatan } & \text { warga } \\
\text { terpenuhi } & \text { dengan } \\
\text { virtual care. } & \end{array}$ & $\begin{array}{l}\text { Hak Klaim } \\
\text { Asuransi } \\
\text { Kesehatan } \\
\text { Klien yang } \\
\text { Tidak } \\
\text { Terpenuhi }\end{array}$ \\
\hline 3 & $\begin{array}{l}\text { Friedlich et al. } \\
\text { (2021) }\end{array}$ & $\begin{array}{l}\text { Journal of Stroke and } \\
\text { Cerebrovascular } \\
\text { Diseases }\end{array}$ & $\begin{array}{l}\text { Amerika } \\
\text { Serikat }\end{array}$ & $\begin{array}{lr}\text { Angka } & \text { morbiditas } \\
\text { stroke } & \text { semenjak } \\
\text { pandemi } & \text { COVID-19 } \\
\text { meningkat. } & \text { Selain itu, }\end{array}$ & $\begin{array}{l}\text { Hak Klaim } \\
\text { Asuransi } \\
\text { Kesehatan } \\
\text { Klien yang }\end{array}$ \\
\hline
\end{tabular}


Lukman Handoyo, Agus Setiawan, Poppy Fitriyani : Situasi Pembiayaan Kesehatan Untuk Manajemen ....

\begin{tabular}{|c|c|c|c|c|c|}
\hline No & $\begin{array}{l}\text { Author dan } \\
\text { Tahun } \\
\text { Publikasi } \\
\end{array}$ & $\begin{array}{c}\text { Nama Jurnal dan } \\
\text { Sumber Database } \\
\text { Akademik }\end{array}$ & $\begin{array}{c}\text { Negara } \\
\text { yang } \\
\text { Dibahas }\end{array}$ & $\begin{array}{c}\text { Data Inti yang } \\
\text { Relevan }\end{array}$ & $\begin{array}{l}\text { Analisis } \\
\text { Tema }\end{array}$ \\
\hline & & Scopus & & $\begin{array}{l}\text { klien dengan stroke } \\
\text { kehilangan hak atas } \\
\text { asuransi kesehatannya, } \\
\text { termasuk jadwal } \\
\text { fisioterapis. }\end{array}$ & $\begin{array}{l}\text { Tidak } \\
\text { Terpenuhi }\end{array}$ \\
\hline 4 & $\begin{array}{l}\text { Halcomb et al. } \\
\text { (2020) }\end{array}$ & $\begin{array}{l}\text { Journal of Nursing } \\
\text { Management } \\
\text { Scopus }\end{array}$ & Australia & $\begin{array}{l}\text { Pelayanan telehealth } \\
\text { oleh perawat pelayanan } \\
\text { primer masih butuh } \\
\text { dukungan pemerintah } \\
\text { agar bisa ditagihkan } \\
\text { (klaim). }\end{array}$ & $\begin{array}{l}\text { Klaim } \\
\text { Pelayanan } \\
\text { Konsultasi } \\
\text { Digital } \\
\end{array}$ \\
\hline 5 & $\begin{array}{l}\text { Hussain } \quad \& \\
\text { Arif (2021) }\end{array}$ & $\begin{array}{lr}\text { Journal } & \text { of } \\
\text { Pharmaceutical } & \text { Policy } \\
\text { and Practice } & \\
\text { PubMed } & \end{array}$ & Pakistan & $\begin{array}{l}\text { Sejak Pandemi COVID- } \\
\text { 19, pemerintah daerah } \\
\text { salah satu provinsi di } \\
\text { Pakistan mengeluarkan } \\
\text { kebijakan asuransi } \\
\text { kesehatan yang dapat } \\
\text { menjangkau seluruh } \\
\text { warganya. }\end{array}$ & $\begin{array}{l}\text { Kebijakan } \\
\text { Baru } \\
\text { Pembiayaan } \\
\text { Kesehatan } \\
\end{array}$ \\
\hline 6 & $\begin{array}{l}\text { Ohannessian } \\
\text { et al.(2020) }\end{array}$ & $\begin{array}{l}\text { JMIR Public Health and } \\
\text { Surveillance } \\
\text { Google Scholar }\end{array}$ & Prancis & $\begin{array}{l}\text { Kegiatan telekonsultasi } \\
\text { sudah diakui sebagai } \\
\text { bagian dari pelayanan } \\
\text { dan dapat ditagihkan } \\
\text { dalam skema National } \\
\text { Health Insurance. }\end{array}$ & $\begin{array}{l}\text { Klaim } \\
\text { Pelayanan } \\
\text { Konsultasi } \\
\text { Digital }\end{array}$ \\
\hline 7 & $\begin{array}{l}\text { Modesti et al. } \\
\text { (2020) }\end{array}$ & $\begin{array}{l}\text { BMC Medicine } \\
\text { PubMed }\end{array}$ & Prancis & 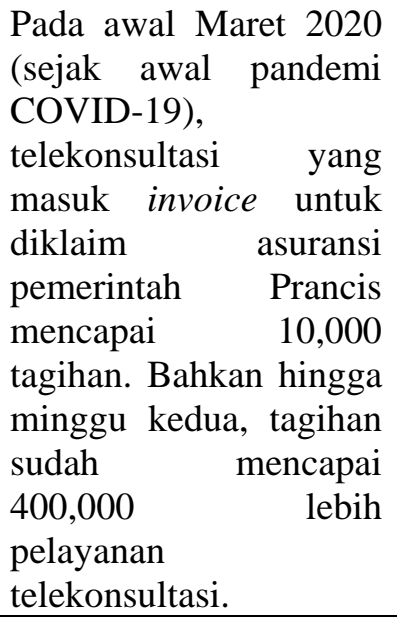 & $\begin{array}{l}\text { Klaim } \\
\text { Pelayanan } \\
\text { Konsultasi } \\
\text { Digital }\end{array}$ \\
\hline
\end{tabular}

Berdasarkan hasil analisis dan sintesis dari artikel-artikel tersebut, maka dapat dirumuskan beberapa topik utama yang menjadi tema dalam studi literatur ini, yaitu: (1) Keterbatasan Anggaran di Pelayanan Primer; (2) Klaim Pelayanan Konsultasi Digital; (3) Hak Klaim Asuransi Kesehatan Klien yang Tidak Terpenuhi; dan (4) Kebijakan Baru Pembiayaan Kesehatan. 


\section{PEMBAHASAN}

\section{Keterbatasan Anggaran di Pelayanan Primer}

Di Amerika Serikat, suatu studi menyoroti bahwa dengan adanya COVID-19, dampak dari kekeliruan sistem pembiayaan di pelayanan primer negara tersebut justru menjadi semakin tampak (Domingues \& Willis, 2020). Hal itu dibuktikan dengan banyaknya kasus COVID-19 yang terjadi disebabkan karena komorbid PTM masyarakat yang tidak terkontrol dengan baik di pelayanan primer. Bahkan, kejadian morbiditas stroke juga semakin meningkat semenjak era COVID-19 (Friedlich et al., 2021). Domingues \& Willis (2020) mengungkapkan, pemerintah Amerika Serikat hanya mengeluarkan biaya kurang dari 50\% dari total alokasi pembelanjaan kesehatan untuk fasilitas pelayanan primer. Padahal, di negara yang sama-sama maju lainnya bisa lebih dari angka tersebut.

Dengan biaya yang tidak besar, ini mengindikasikan, jalannya program promotif dan preventif di pelayanan primer memang bisa jadi tidak terlalu optimal selama ini. Lebih lanjut, studi oleh Domingues \& Willis (2020) menjelaskan, di Amerika Serikat masalah kesehatan yang dominan menyerang masyarakat adalah memang PTM yang pada dasarnya mampu dikendalikan dan dicegah dengan modifikasi gaya hidup. Misalnya, dengan mengendalikan berat badan (diketahui, sebesar 40\% warga Amerika berstatus obesitas). Hasil analisis dalam studi tersebut menuliskan pula, pemerintah Amerika Serikat malah justru menghabiskan biaya hingga 33\% lebih tinggi dibanding negara maju lainnya untuk biaya hospitalisasi penyakit yang dapat dikontrol di pelayanan primer seperti hipertensi dan diabetes melitus. Selain itu, klaim dari rumah sakit pada pihak asuransi pemerintah diduga banyak indikasi pengobatan dan tindakan operatif yang sebenarnya tidak perlu. Melalui penjabaran ini, nampaknya revitalisasi pembiayaan kesehatan di pelayanan primer Amerika Serikat cukup diperlukan agar dapat lebih optimal dalam menjalankan kegiatan promotif dan preventif pengendalian PTM.

\section{Klaim Pelayanan Konsultasi Digital}

Di Australia, pelayanan virtual care atau telehealth yang banyak diandalkan sebagai alternatif pelayanan di era pandemi COVID-19 justru masih belum sepenuhnya dapat diakui dan ditagihkan oleh perawat yang bekerja di pelayanan primer (Halcomb et al., 2020). Akibatnya, isu tentang kualitas pelayanan pun timbul dari pemberian pelayanan secara virtual (Halcomb et al., 2020). Perawat komunitas yang memberikan pelayanan membutuhkan kebijakan adanya mekanisme penagihan kepada pemerintah, 
Lukman Handoyo, Agus Setiawan, Poppy Fitriyani : Situasi Pembiayaan Kesehatan Untuk Manajemen ....

agar kegiatan yang dilakukannya dapat terasa dihargai (Halcomb et al., 2020). Sebab, kegiatan virtual care yang dilakukan oleh perawat komunitas di Australia tidak jarang justru mengelola kasus klien dengan PTM kronis sehingga sekali melakukan virtual care, pelayanan asuhan keperawatan yang diberikan cukup kompleks (Halcomb et al., 2020). Lebih lanjut dalam studi Halcomb et al. (2020) diceritakan dari hasil studi kualitatifnya bagaimana perawat komunitas menginginkan pembayaran yang sesuai untuk dirinya, paling tidak sama dengan perawat yang bekerja di rumah sakit. Perawat komunitas di Australia merasa beban kerja di primary care juga berat, terlebih di era pandemi COVID19, sehingga mereka merasa pantas mendapatkan dukungan pendapatan lain dari skema pembiayaan kesehatan pemerintah. Dampak yang bisa timbul apabila mekanisme klaim ini tidak ada untuk perawat komunitas sebetulnya juga sudah dituliskan dalam studi ini, yaitu munculnya isu retensi perawat yang lemah.

Berbeda halnya dengan Australia, di negara Prancis, sejak awal pandemi pada Maret 2020, kegiatan telekonsultasi sudah diakui oleh pemerintah sebagai bagian dari layanan kesehatan (termasuk pelayanan primer) yang dapat ditagihkan ke National Health Insurance (NHI) (Modesti et al., 2020; Ohannessian et al., 2020). Kementerian Kesehatan Prancis sudah menandatangani surat keputusan tentang mekanisme reimbursement dari kegiatan telekonsultasi video oleh NHI sejak 9 Maret 2020 (Ohannessian et al., 2020). Keputusan tersebut dibuat untuk mengurangi adanya perjalanan masyarakat untuk konsultasi ke pelayanan kesehatan. Bahkan, sejak minggu pertama paska keputusan disahkan, sekitar 10,000 telekonsultasi sudah masuk ke dalam tagihan NHI agar segera dibayarkan pemerintah pada tenaga kesehatan yang berperan (Modesti et al., 2020; Ohannessian et al., 2020). Hal lain yang menarik, di Prancis secara tegas semenjak wabah COVID-19 semakin memburuk, turut melegalkan dan mengakui klaim pembiayaan dari kegiatan pelayanan telekonsultasi yang dilakukan oleh perawat, bidan, dan terapis wicara (Ohannessian et al., 2020). Kegiatan pelayanan telekonsultasi direkomendasikan pula oleh Konsil Tinggi Kesehatan Masyarakat Prancis agar dilaksanakan tatanan pelayanan primer dengan memprioritaskan masyarakat dengan penyakit yang parah, termasuk PTM kronis (Ohannessian et al., 2020). Dengan adanya kejelasan mekanisme pembiayaan seperti ini, maka bukan tidak mungkin pengontrolan kesehatan masyarakat dengan PTM dapat lebih baik sehingga dapat membantu menurunkan kejadian COVID-19 disertai komorbid.

Berdasarkan penjelasan artikel-artikel tersebut, maka dapat disimpulkan bahwa pembiayaan kesehatan di pelayanan primer perlu betul-betul diperhatikan bagaimana 
algoritmanya jika pelayanan dilakukan dalam bentuk lain selain bertemu langsung (virtual). Apakah bisa dianggap sebagai bentuk pelayanan dan kemudian dapat ditagihkan atau tidak. Jangan sampai justru inovasi yang dilakukan oleh perawat guna tetap memberikan pelayanannya yang terbaik menjadi sia-sia.

\section{Hak Klaim Asuransi Kesehatan Klien yang Tidak Terpenuhi}

Dalam studi lain, dijabarkan bahwa di Amerika Serikat sebetulnya sudah banyak care provider (termasuk pelayanan primer) yang mengalihkan pelayanan manajemen PTM seperti diabetes melitus dari yang bertemua langsung menjadi kegiatan virtual care (Hartmann-Boyce et al., 2020). Kegiatan virtual care ini pun sudah diakui oleh pemerintah dan dapat dilakukan reimbursement atau klaim seperti layaknya konsultasi langsung (Domingues \& Willis, 2020). Tetapi, ternyata tetap saja klien tidak dapat sepenuhnya mendapat hak dari insurance coverage-nya. Hal tersebut dibuktikan dengan data yang menunjukkan bahwa peresepan obat menurun 10\%. Pada kasus diabetes melitus, setiap 1 dari 6 pasien yang ketergantungan dengan insulin tidak mendapatkan hak atas insulinnya semenjak pandemi COVID-19 (Hartmann-Boyce et al., 2020). Pada kasus stroke, klien kehilangan hak atas jadwal fisioterapinya (Friedlich et al., 2021). Artinya, manajemen perawatan PTM meski berbasis virtual, tetap harus difollow up dengan baik sampai klien mendapatkan hak sesuai kebutuhan atas asuransi kesehatannya. Jangan sampai, inovasi virtual care justru menjadi penghalang tercapainya UHC.

\section{Kebijakan Baru Pembiayaan Kesehatan}

Di negara Pakistan, semenjak pandemi COVID-19 terjadi, salah satu provinsinya yang bernama Khyber Pakhtunkhwa mengeluarkan program asuransi kesehatan yang diakomodir sendiri oleh pemerintah daerah (Hussain \& Arif, 2021). Pada intinya, provinsi tersebut mengeluarkan kebijakan skema asuransi pemerintah daerah bukan tanpa alasan. COVID-19 yang dipandang sebagai penyebab krisis kesehatan pasti akan membuat banyak problematika kesehatan lainnya tanpa pandang status. Sedangkan Sehat Sahulat Program, skema asuransi nasional yang sudah ada di Pakistan sebelumnya cenderung hanya untuk keluarga dengan ekonomi menengah ke bawah. Oleh karena itu provinsi ini mengeluarkan skema asuransi kesehatan untuk seluruh warganya tanpa terkecuali, meski skema asuransi nasional pun tetap ada. Bahkan skema asuransi yang dikeluarkan mampu mengakomodir seluruh aspek kesehatan, dari mulai perawatan penyakit kronis tidak menular (ginjal, jantung, saraf, diabetes), kesehatan maternal, tatalaksana kanker, hingga 
Lukman Handoyo, Agus Setiawan, Poppy Fitriyani : Situasi Pembiayaan Kesehatan Untuk Manajemen ....

perawatan ICU (Hussain \& Arif, 2021). Skema asuransi ini mampu membiayai sekitar 40 ribu penduduk di provinsi tersebut, dengan asumsi biaya per orang sekitar USD1,200 (Hussain \& Arif, 2021). Prinsip utama penyelenggaraan skema asuransi ini adalah dengan berpedoman pada UHC. Penyelenggaraan skema asuransi berbasis UHC merupakan hal yang baik dimunculkan saat era pandemi COVID-19. Karena, krisis kesehatan di era pandemi COVID-19 memang tidak dapat diprediksikan dapat menyerang siapa. Belum tentu keluarga dengan tingkat ekonomi menengah atas pasti aman. Prinsip UHC sendiri adalah menekankan pada siapa pun dan dimana pun manusia berada maka manusia itu berhak atas pelayanan kesehatan sesuai kebutuhannya. Tidak harus langsung menuju tatalaksana kuratif, tetapi penting pula memerhatikan kebutuhan kesehatan dari segi promotif dan preventif.

\section{SIMPULAN}

Gambaran situasi pembiayaan kesehatan untuk perawatan klien dengan PTM di pelayanan primer berbagai negara selama pandemi COVID-19 memiliki karakteristiknya sendiri. Di Amerika Serikat dan Prancis, mekanisme pembiayaan kesehatan untuk klaim kegiatan pelayanan virtual atau telekonsultasi manajemen PTM sudah diakui oleh pemerintah. Sedangkan, di Australia, klaim untuk perawat yang bekerja di primary care masih perlu dukungan pemerintah. Namun, di Amerika Serikat ternyata alokasi pembiayaan kesehatan di tatanan layanan primer cenderung lebih rendah dibanding negara maju lainnya. Berbeda konteks situasi dengan ketiga negara tersebut, di Pakistan, salah satu pemerintah daerah provinsinya mengeluarkan kebijakan baru tentang mekanisme pembiayaan kesehatan yang berbasis pada UHC sehingga dapat menyasar pada seluruh tingkat pelayanan kesehatan dan tatanan lapisan masyarakat. Meski PTM berkontribusi tinggi terhadap kematian dan kesakitan masyarakat dan sejatinya dapat dicegah di tatanan pelayanan primer (komunitas), namun orientasi pembiayaan pada kuratif masih lebih dominan dirasakan pada beberapa negara. Paradigma UHC menjadi penting sebagai fondasi agar pelayanan primer dapat semakin kuat, baik dari segi pembiayaan maupun pelayanan.

\section{UCAPAN TERIMA KASIH}

Ucapan terima kasih penulis sampaikan kepada seluruh staf pengajar Program Studi Magister Ilmu Keperawatan, Fakultas Ilmu Keperawatan, Universitas Indonesia atas dukungan moril dan fasilitas literasi yang diberikan sehingga proses pengerjaan artikel ini berlangsung dengan lancar. Selain itu, penulis pertama juga mengucapkan 
terima kasih kepada Sekolah Tinggi Ilmu Kesehatan Widya Dharma Husada Tangerang, yang telah memberikan dukungan finansial dalam upaya penyelesaian artikel ini.

\section{DAFTAR PUSTAKA}

Amadeo, K. (2021). Why Preventive Care Lowers Health Care Costs. The Balance. https://www.thebalance.com/preventive-care-how-it-lowers-acacosts-3306074

Annaswamy, T. M., Verduzco-Gutierrez, M., \& Frieden, L. (2020). Telemedicine barriers and challenges for persons with disabilities: COVID-19 and beyond. Disabil Health J, 13(4). https://doi.org/10.1016/j.dhjo.2020.100973

Barroy, H., Wang, D., Pescetto, C., \& Kutzin, J. (2020). How to budget for COVID-19 response?A rapid scan of budgetary mechanisms in highly affected countries. https://www.who.int/publications/m/item/how-to-budgetfor-covid-19-response

Bielska, I. A., Manis, D. R., Schumacher, C., Moore, E., Lewis, K., Agarwal, G., Mondoux, S., Jewett, L., Speicher, D. J., Liu, R. H., Leyenaar, M., McLeod, B., \& Upadhye, S. (2020). Health Sector responses to the COVID-19 pandemic in Ontario, Canada - January to May 2020. Zdrowie Publiczne $i$ Zarzadzanie, 18(1). https://doi.org/10.4467/208426270Z.20.010.12664

Blumel, M., Achstetter, K., Koppen, J., \& Busse, R. (2020). Financial risk protection of individuals with private health insurance. European Journal of Public Health, 30(Supplement_5). https://doi.org/10.1093/eurpub/ckaa165.910

Chang, A. Y., Cullen, M. R., Harrington, R. A., \& Barry, M. (2021). The impact of novel coronavirus COVID-19 on noncommunicable disease patients and health systems: a review. Journal of Internal Medicine, 289. https://doi.org/10.1111/joim.13184

Collins, S. R., Gunja, M. Z., \& Aboulafia, G. N. (2020). U.S. Health Insurance Coverage in 2020: A Looming Crisis in Affordability. The Commonwealth Fund. $\quad$ https://www.commonwealthfund.org/publications/issuebriefs/2020/aug/looming-crisis-health-coverage-2020-biennial

Cutler, D. (2020). How Will COVID-19 Affect the Health Care Economy? JAMA Health Forum. https://doi.org/10.1001/jamahealthforum.2020.0419

Domingues, L. W., \& Willis, J. S. (2020). COVID-19 and the Case for Medical Management and Primary Care. Journal of Primary Care \& Community Health, 11. https://doi.org/10.1177/2150132720965080

Erlangga, D., Suhrcke, M., Ali, S., \& Bloor, K. (2019). The impact of public health insurance on health care utilisation, financial protection and health status in low- and middle-income countries: A systematic review. PLoS ONE, 14(8). https://doi.org/10.1371/journal.pone.0219731

Friedlich, D., Newman, T., \& Bricker, S. (2021). Impact of the COVID-19 Pandemic on Stroke Epidemiology and Clinical Stroke Practice in the US. Journal of Stroke and Cerebrovascular Diseases, 30(4). https://doi.org/10.1016/j.jstrokecerebrovasdis.2021.105639 
GBD 2019 Diseases and Injuries Collaborators. (2020). Global burden of 369 diseases and injuries in 204 countries and territories, 1990-2019: a systematic analysis for the Global Burden of Disease Study 2019. Global Health Metrics, 396(10258), p1204-1222. https://doi.org/10.1016/S01406736(20)30925-9

Gummidi, B., John, O., \& Jha, V. (2020). Continuum of care for noncommunicable diseases during COVID-19 pandemic in rural India: A mixed methods study. Journal of Family Medicine and Primary Care, 9(12). https://doi.org/10.4103/jfmpc.jfmpc_1805_20

Halcomb, E., Halcomb, E., Ashley, C., \& McInnes, S. (2020). The support needs of Australian primary health care nurses during the COVID-19 pandemic. Journal of Nursing Management, 28(7). https://doi.org/10.1111/jonm.13108

Hartmann-Boyce, J., Morris, E., Goyder, C., Kinton, J., Perring, J., Nunan, D., \& Mahtani, K. (2020). Diabetes and COVID-19: Risks, Management, and Learnings from Other National Disasters. Diabetes Care, 43. https://doi.org/10.2337/dc20-1192

Hussain, R., \& Arif, S. (2021). Universal health coverage and COVID19: recent developments and implications. Journal of Pharmaceutical Policy and Practice, 14(23). https://doi.org/10.1186/s40545-021-00306-x

Jolly, W. (2018). Australian Health Insurance Statistics. Canstar. https://www.canstar.com.au/health-insurance/who-has-health-insurance/

Mahendradhata, Y., Trisnantoro, L., Listyadewi, S., Soewondo, P., Marthias, T., Harimurti, P., \& Prawira, J. (2017). The Republic Indonesia Health System Review (Vol. 7 No.). WHO.

Modesti, P. A., Wang, J., Damasceno, A., Agyemang, C., \& Bortel, L. Van. (2020). Indirect implications of COVID-19 prevention strategies on noncommunicable diseases: An Opinion Paper of the European Society of Hypertension Working Group on Hypertension and Cardiovascular Risk Assessment in Subjects Living in or Emigrating from Low Re. BMC Medicine, 18(256). https://doi.org/10.1186/s12916-020-01723-6

Nurmansyah, M. I., \& Kilic, B. (2017). Impact of National Health Insurance Policy towards theImplementation of Health Promotion Program at PublicHealth Centers in Indonesia. Kesmas: National Public Health Journal, 11(3), 103-110. https://doi.org/10.21109/kesmas.v11i3.1262

Ohannessian, R., Duong, T. A., \& Odone, A. (2020). Global Telemedicine Implementation and Integration Within Health Systems to Fight the COVID19 Pandemic: A Call to Action. JMIR Public Health and Surveillance, 6(2). https://doi.org/10.2196/18810

Rhatomy, S., \& Prasetyo, T. E. (2020). Impact of COVID-19 on primary care visits: Lesson learnt from the early pandemic period. Journal of Community Empowerment for Health, 3(2). https://doi.org/10.22146/jcoemph.57918

Triana, A. J., Gusdorf, R. E., Shah, K. P., \& Horst, S. N. (2020). Technology Literacy as a Barrier to Telehealth During COVID-19. Telemedicine and EHealth, 26(9). https://doi.org/10.1089/tmj.2020.0155

Unger, J.-P., \& Paepe, P. De. (2019). Commercial Health Care Financing: The Cause of U.S., Dutch, and Swiss Health Systems Inefficiency? International 
Journal of Health Services, https://doi.org/10.1177/0020731419847113

WHO. (2020). COVID-19 significantly impacts health services for noncommunicable diseases. World Health Organization. https://www.who.int/news/item/01-06-2020-covid-19-significantly-impactshealth-services-for-noncommunicable-diseases

Wiseman, V., Thabrany, H., Asante, A., Haemmerli, M., Kosen, S., Gilson, L., Mills, A., Hayen, A., Tangcharoensathien, V., \& Patcharanarumol, W. (2018). An evaluation of health systems equity in Indonesia: study protocol. International Journal for Equity in Health, 17(138). https://doi.org/10.1186/s12939-018-0822-0

\begin{tabular}{|l|l|}
\hline Submission & 23 Maret 2021 \\
\hline Review & 24 Maret -30 Maret 2021 (Fastrack Review) \\
\hline Accepted & 1 April 2021 \\
\hline Publish & 12 April 2021 \\
\hline DOI & 10.29241/jmk.v\%vi\%i.615 \\
\hline Sinta Level & Tiga (3) Nasional Akreditasi \\
\hline
\end{tabular}

